\title{
College Cultural Inheritance and Innovation and College English Teaching
}

\author{
Liming Zhang \\ Yancheng Institute of Industry Technology, Yancheng, 224001, China
}

\begin{abstract}
Keywords: College culture; Inheritance and innovation; College English teaching; Fundamental objective
\end{abstract}

\begin{abstract}
As the foundation course teaching of college, the college English teaching can train the students' English listening, speaking, reading and writing skills and can meet the demand of social development of this stage. For national and cultural development, the cultural inheritance and innovation of college is the fundamental objective to carry out the college English teaching ${ }^{[1]}$. For the inheritance and innovation of college culture, it is required to carry out corresponding reforms in college English teaching to enhance both the cultural concept of English teaching and it is also required to carry out practical teaching with the cultural inheritance and innovation as the basic starting point of college English teaching. This paper mainly studies the relationship between the cultural inheritance and innovation and the college English teaching so as to improve the quality of college English teaching and to develop the inheritance and innovation of college culture.
\end{abstract}

\section{Introduction}

Culture, which is the basis of spiritual civilization, is a process of integration and permeation of information and, meanwhile, a power to maintain and guide spiritual civilization. For a country, culture is a social phenomenon in a country and a product formed after people's long-term creation and historic experience accumulation so it contains the significant thought of the country and is the important content for the steady development of a country, playing an important guiding and protecting role in the development of the country and people's life ${ }^{[2]}$. With the social and economic development of our country, ceaseless reforms in college education are made to enable it to adapt to the social demands and development at this stage; besides, because of the influence of economic globalization, an increasing number of foreign companies were founded in China, which has higher requirements for students' English level. Therefore, it is required to make reforms in the college English teaching so that such teaching can meet the current development of society; at the same time, the purpose of college teaching falls into four aspects below respectively: cultural inheritance and innovation, training talents, strengthening the ability of scientific research and making contributions to the society. It is also required to carry out inheritance and innovation of college culture while conducting college teaching. Developing teaching is the foundation of cultural inheritance and innovation, which is the fundamental objective of developing teaching; namely, strengthen the students' English skills; then, the students will spread Chinese culture internationally and continuously inherit Chinese traditional culture and innovatively develop it.

\section{The relationship between the inheritance and innovation of college culture and college English teaching}

The most basic teaching objective of college English teaching is to promote the students to learn English knowledge so that they can make communications in English smoothly. But such communication is not the fundamental objective of college English teaching. It is hoped that the developing of college English teaching can train more talents for the development of our country, enhance the educational development of our country and serve the social and economic construction in our country so that we can have more deep trades and communications with other countries and then our country's international standing and influence can be enhanced accordingly ${ }^{[3]}$. That is to say, 
it aims at driving our country's development to the world and spreading our culture to the world, so the fundamental objective of college English learning is the inheritance and innovation of Chinese culture.

\section{Learning excellent foreign culture with the media of college English teaching}

A language not only is the carrier for communication but also shows the cultural thoughts and cultural development of a country, since it coheres the national sprit and is also an essential tool for the development and cultural transmission of a country. Developing the college English teaching can help the students to learn the excellent foreign cultures, understand the cultural information contained in English articles, learn and understand the foreign manners and customs, economic development, geographic location distribution, technical development, religious faiths etc. through learning English ${ }^{[4]}$ so that the students can learn the excellent cultures which is good for better utilization of English and communication in English in their future work.

\section{Cultivating the learning of culture with the basis of college English teaching}

Our country's development requirements for culture are to face the modernization, face the world and face the future. Learning English is able to promote our country's cultural communications and understanding with other countries, which is convenient for spreading the outstanding Chinese culture. For this reason, while carrying out the college English teaching, the teachers should take the spreading of outstanding Chinese culture as the objective of teaching, ceaselessly deepen the students' learning and understanding of cultural knowledge so that the students can form the traditional ideological value of spreading Chinese culture and continuously enhance their English learning skills as well as the English application ability for Chinese culture.

\section{Realizing cultural transmission with the fundamental of college English teaching}

If a country wants to develop and grow, it must strengthen the development of national politics, economy and culture. Thus it can be seen how important the culture is for the development of a country. To develop college English teaching is not only to make the students to simply learn English knowledge but also to help them integrate Chinese culture into English learning and continuously deepen the students' English learning for cultural knowledge so that they can use it and develop well in the future. After college English learning, the students can improve their English level and, afterwards, they can make cultural exchanges international in the future to realize the transmission of excellent Chinese culture.

\section{Existing problems of college English teaching at this stage}

The inheritance and innovation of college culture is the fundamental objective of college English teaching. But there are many problems in the college English teaching at this stage, causing the teaching objective of college English teaching deviating from the objective of spreading Chinese culture. There are basically the three problems below:

\section{No emphasis on the cultivation of cultural concept in college English teaching}

The current college English teaching pay no sufficient emphasis on the generation of its cultural concept but simply teaches and explains English knowledge, neglecting cultivating the students' ability of cultural learning and utilization. Besides, there are a lot of English exams in college years; since the grades of such exams directly influence their graduation ${ }^{[5]}$, the students learn mainly for exams without targeting the cultivation of cultural concept in learning, which goes against the transmission of Chinese culture in the future.

\section{No sufficient content of cultural teaching in college English teaching}

To develop teaching is to explain the teaching content, which amounts to the intermediate species. If the teachers hope to train the students' ability of cultural learning, they cannot achieve it without teaching content. But in the college English teaching at this stage, there is the phenomenon of lacking cultural teaching content; students only learn simple words, sentences and grammars rather than learn and understand the cultural phenomenon behind English. Besides, in the college English teaching, the teaching content seldom gets involved in the content of Chinese culture, which goes against cultivating the students' cultural thoughts. 


\section{No corresponding cultural environment and low cultural quality of teachers in college English teaching}

Basic classroom teaching is adopted in college English teaching; namely, the teachers give lessons and the students listen to them in the class. To enhance their teaching quality, even though students obtained good scores in exams, the teachers only explains textbook knowledge to them and seldom extend corresponding cultural knowledge, causing no favorable cultural environment for college English teaching. Meanwhile, there is also the phenomenon of low cultural quality of college English teachers. If the college English teachers, who directly explain knowledge to the students, have no corresponding cultural quality, they must exert influences on the students' forming of cultural knowledge. Generally, the college English teachers come from normal schools, they have pretty good specialized English knowledge and application ability, but they have no corresponding cultural quality; so they only carry out routine teaching for students without cultivating their ability of cultural thoughts, resulting in the college English teaching deviating from the college teaching objective. If this phenomenon continues, the students cannot spread the excellent Chinese culture in their future development, because they will lose their awareness and ability of spreading cultures.

\section{College English teaching's strategies for realizing the inheritance and innovation of college culture}

With the rather rapid development and reforms of the world and China, China's modern English teaching have deviated from the mission of cultural inheritance and innovation, which goes against the transmission and development of Chinese culture. There are four strategies below to cope with the changes of world environment and to inherit and spread the culture better.

\section{Strengthening the cultural connotation of college English teaching}

To guide the teaching objective of college English teaching to the inheritance and innovation of college culture, it is required to strengthen the cultural connotation of college English teaching and standardize the teaching objective of college English so as to achieve inheritance and innovation of college culture in college English teaching. The basic objective of college English teaching is to cultivate the students' basic English ability so that they can make communications internationally in the future. Thus, it is required to continuously strengthen the students' basic English knowledge and application ability, which is the most basic requirement. To realize the inheritance and innovation of culture, it is also required to enhance the students' basic cultural quality, because culture transmission is cultural communication, which is a interactive process and the premise of communication is that both parties can understand the other side's language and thoughts ${ }^{[6]}$. Therefore, while carrying out college English teaching, the teachers need to command such process of cultural communication. They need not only to explain the English words and articles but also to introduce the cultures and customs of foreign countries to cultivate the students' view of learning and value for spreading excellent Chinese culture; furthermore, the purpose of learning English is not purely for future communication but for understanding excellent foreign culture; then they can combine the foreign culture with the traditional Chinese culture to realize the innovation and development of culture.

\section{Improving the cultural content of college English teaching}

The college English teaching at this stage only involves learning simple words, sentences, grammars and a little cultural content. To realize the objective of cultural inheritance and innovation, it is required to enrich the cultural content in college English teaching. The state shall uniformly compile the college English textbooks, perfects the cultural content in textbooks, enhances the students' learning of cultural knowledge and, meanwhile, cultivates the students' corresponding cultural quality to promote their development in an all-around way. While practically carrying out college English teaching, the teachers shall impart the knowledge about English culture and traditional Chinese culture to the students through textbooks rather than only take English teaching as a foreign acculturation; the students shall learn the traditional Chinese culture in English teaching textbooks to spread traditional Chinese culture better later ${ }^{[7]}$. Therefore, it is required to perfect the 
cultural content in college English teaching from the basically-applied textbooks, contents and teaching so as to lay a solid foundation for spreading excellent Chinese culture better in the future.

\section{Constructing the cultural environment for college English teaching}

As a matter of fact, the learning of English words, sentences and grammar is a kind of learning of culture and learning of different composition modes of a language. Our college English teaching at this stage blindly emphasizes exams rather than cultivates the students' practical ability of English application and the students only rigidly recite words, sentences and texts, neglecting learning English cultures, so we need to reform such college English teaching pattern and to build the cultural environment for college English teaching. In the practical classroom teaching, the teachers need to weaken the importance of English exams but to strengthen the learning and application ability of cultures in English; meanwhile, it is also required to reform the college English exams, such as CET4, CET6, TEM4, TEM8 and other English exams and not to use them as the standards to limit the students' successful graduation. They should strengthen the students' crisis awareness of English learning, integrate cultural content into teaching and exams so that the students can develop good habits for utilizing culture. Meanwhile, to construct the cultural environment of college English teaching, the teachers need to strengthen their own ability of cultural teaching, to help the students to adapt to such teaching pattern dominated by cultural teaching and to carry out a lot of publicity for English culture at campus. Teaching in such English cultural environment can help the students to form their professional cultural application behaviors.

\section{Enhancing the college English teachers' cultural quality}

If the college English teachers, who directly impart English culture and knowledge to the students, have no high cultural quality, they cannot cultivate the students, who have rather good ability of culture application, during their English teaching. For this reason, it is required to enhance the college English teachers' cultural quality and to train the students' thought of spreading culture. While improving their cultural quality, the college English teachers understand English knowledge with the Chinese language and grammars. This shows that English learning cannot be separated with the learning of Chinese culture. While carrying out English teaching, the teachers need to improve their own knowledge about Chinese culture to promote the students to deeply understand the essence of English culture and to cultivate the students' integration with Chinese culture and English culture so that the students can understand English content with the Chinese thinking and can reflect Chinese culture with English content. The teachers should also strengthen the cultural permeation in English teaching to enhance the content of traditional Chinese culture in the students' thinking so that they can spread our culture in English.

\section{Conclusion}

To sum up, this paper mainly studies and discusses the relationship between the inheritance and innovation of college culture and the college English teaching. The college English teaching is the most basic teaching content in colleges and cultivates the students' professional knowledge and application skills. Since one of the objectives of college teaching is the inheritance and innovation of culture, it is required to continuously improve the pattern and content of English teaching while the teachers carry out college English teaching to enhance the students' awareness of learning culture. In the future development, to realize the transmission and innovation of traditional Chinese culture through English will has a practical significance in the development of China's social standing.

\section{References}

[1] Zheng Xuesong. The Value of Inheriting Traditional Chinese Culture in College English Teaching. Age of Literature, 2010,(10):77-78.

[2] Qi Mingjun. Function of Cultural Inheritance in English Teaching. China Education Innovation Herald, 2007,(16):82-83. 
[3] Che Lulu. Brief Talk about the Emotional Education in College English Teaching. Journal of Hubei University of Science and Technology, 2013,33(1):70-71.

[4] Yu Qinmei. Discussion about the Cultural Traits of English Teaching in China. Journal of Suzhou University (Philosophy and Social Science Edition), 2010,31(5):190-192.

[5] Zhang Ming. Reflection of College Students' Humanistic Quality Education in College English Teaching. Weekly of Examinations, 2013,(79):65.

[6] Duan Youguo. Guiding Significance of Language's Cultural Function to College English Teaching. Journal of Hotan Teachers College: Chinese Culture Integration Edition, 2012,(5):78-80.

[7] Jiang Li, Pan Jie. Brief Analysis on Cultural Teaching in College English Teaching. Reading and Writing Periodical (Education and Teaching Periodical), 2010,07(8):20. 